\title{
Evidence on Funding Decisions by Italian SMEs: A Self-Selection Model?
}

\author{
Paola Brighi and Giuseppe Torluccio*
}

This version: February 1st 2008

\begin{abstract}
:
This paper sets out to analyse the determinants of Italian SMEs' choices of sources of finance, with specific reference to the role of informed (internal) capital compared to other forms of finance. In this work, we aim to identify the determinants of the mix of sources of finance using data from the Survey of Italian Firms conducted by Capitalia, bearing in mind the structural characteristics of the firms and the banking market, and the problems of the information asymmetry between the bank and the firm. Although the financial hierarchy theory suggests that firms prefer selffinancing, because it is less expensive in economic terms, relationships with local banks may offer advantages which encourage firms to enter into debt contracts even in the absence of binding internal constraints. The empirical study focused in particular on the role of self-financing as an alternative to external sources. In order to measure the decision to use self-financing and the subsequent composition of the financing mix, we used different techniques, first independent models and then a self-selection model. The first results, in line with the pecking order theory, confirm an approach comprising an initial check on the availability of internal resources, followed if by the use of external capital, including bank debt.
\end{abstract}

JEL classification: D21; G21; L15

Keywords: SME; Capital Structure; Banking; Credit; Imperfect information

"[...] it is well known that in the analysis of business cases, two or more solutions usually appear equally defensible. Those who hold to the skeptical position therefore assert that there can be no science of business finance since experts cannot arrive at unique answers".

Weston, 1955 p. 130

* University of Bologna; Department of Management and CREDIF Via Capo di Lucca, 34, 40126 Bologna. E.mail: paola.brighi@unibo.it and giuseppe.torluccio@,unibo.it. 


\section{Introduction}

This paper sets out to analyse the determinants of Italian SMEs' choices of sources of finance, with specific reference to the role of informed (internal) capital compared to other forms of finance. The pecking order theory (Myers, 1984 and Myers-Majluf, 1984) suggests that firms prefer internal to external finance, and that there is a preference for debt over equity when it comes to external sources.

The literature on financial intermediation (from Leland and Pyle, 1977 onwards), offers interesting pointers as to the determinants of SMEs' financial structure, and thus also on the breakdown of the sources of investment financing.

However, from both theoretical and empirical points of view, the question of the motivations underlying the choice of mix of sources of finance is still widely debated, with no conclusive solution yet in sight (Frank and Goyal, 2005). The use of debt as a source of finance implies an increase in the firm's costs and may lead to a greater risk of bankruptcy indipendently from fiscal benefits. The literature on financial intermediation has generally focused on the debt contract, which has often been considered as the optimal method of financing (Leland and Pyle, 1977 and Diamond, 1984). However, as de Meza and Webb (1987) have shown, a number of distorting phenomena such as credit rationing may simply disappear if equity is accepted as an alternative source of finance ${ }^{1}$. Although clear in methodological terms, de Meza and Webb's finding (1987) has not concluded the debate on the problems concerning a firm's financial decisions in conditions of uncertainty.

In fact, the literature contains contradictory findings. On the one hand, some authors assert that high risk firms (defined as small, innovative firms with high information opacity) prefer debt contracts to equity contracts (Hellmann and Stiglitz, 2000). On the other hand, various authors argue that the firm's propensity to choose equity increases in direct proportion to the risk associated to the project they wish to finance. However, whether the resulting equity financing is the outcome of a voluntary ex-ante decision on the part of the entrepreneur (Ueda, 2003 and Landier, 2002) or the consequence of credit rationing by the bank (Bolton and Freixas, 2000) is still a matter requiring further investigation ${ }^{2}$. While on the one hand, credit rationing limits the firm's external finance options, on the other, the firm's opportunity to signal its quality through its collateral may restore the debt

\footnotetext{
${ }^{1}$ de Meza e Webb, 1987, pp. 281-282 write "The structure of information also has implications for the method of finance. Entrepreneurs with projects that are attractive to banks attempt to choose financial structures that signal their characteristics. We are able to show that the assumptions which yield the overinvestment result support debt as the equilibrium method of finance. Interestingly, however, under the Stiglitz-Weiss assumptions, equity rather than debt is shown to be the equilibrium method of finance".

${ }^{2}$ With reference to young, strongly innovation-oriented German SMEs Schäfer et al. (2004) demonstrate the truth of the hypothesis that "Investments with a high intrinsic and financial risk are more likely to be equity than debt-financed. Investments with a low intrinsic and financial risk are more likely to be debt than equity financed" (p. 5).
} 
equilibrium $^{3}$. In other words, the availability of collateral reduces the creditor's financial risk. Bester (1985) considers endogenous collateral as a signalling tool for good quality firms in a self-selection model.

The literature on the optimal mix of the firm's sources of finance also leaves scope for further study from the empirical point of view. Frank and Goyal (2005) study the importance of questionnaires as a tool for empirical survey of the firm's capital structure, and state that although the literature produced is of some interest, at present it is unable to deliver conclusive results.

In this work, we aim to contribute to this discussion by identifying the determinants of the mix of sources of finance with the aid of the data from the Survey of Italian Firms conducted by Capitalia, bearing in mind the structural characteristics of the firms and the banking market, and the problems of the information asymmetry between the bank and the firm. The rest of the paper is structured as follows. The first section summarises the theoretical framework of reference, underlining the effects of the firm's financial structure from the point of view of both the firm itself (point 2.1) and the bank (point 2.2). After a description of the sample used (point 3), the following sections describe the methodological approach adopted for the econometric analysis (point 4). In particular, we study the determinants of the firm's mix of sources of finance in relation to the firm's own structural characteristics, the structure of the banking market and the information asymmetries (point 4.1). Then to understand the firm's financial decisions we adopt a two-stage approach using the self-selection model proposed by Heckman (point 4.2). The conclusion summarises the main findings and offers a number of suggestions for future research (point 5).

\section{The Theoretical Framework}

How do firms finance themselves? How should they finance their investments? What are the factors which influence the firm's financing decisions, and the decisions of SMEs in particular? The economic theories we will be surveying attempt to answer these questions, first from the firm's and then from the bank's point of view.

Traditionally, the firm's market value and real decisions were considered to be unaffected by its financial structure and financing policies, since in the theoretical context generated by Modigliani and Miller's theorem (1958), capital markets were perfect, fiscal neutrality reigned and, therefore, external funds (shares, bonds and debt) and internal funds (self-financing) were perfect substitutes for each other. This led to an approach to investment theory in which the firm's problem of intertemporal optimisation is solved without reference to financial factors, or including them on the basis of assumptions valid in a context of perfect capital markets. Given the hypothesis that all firms have the same access to the capital and information markets and the cost of capital is exogenous, in traditional models the dominant notion is of the "representative firm". But the idea that the same

3 Obviously, as Schafer et al. note, 2004, p. 5 "for high-risk entrepreneurs lacking collateral, this route of returning to the preferred loan market is not open and equity may appear as the only remaining option". 
model can be applied to all firms proved incapable of explaining investments' sensitivity to the financial variables which differ between large, medium and small enterprises ${ }^{4}$. This implies that although the theoretical principles underlying the theory of capital structure may be valid for all firms, there are however institutional or regulatory conditions, or simply operating practices, which lead SMEs to make financial choices different from those of large firms.

After the pioneer work by Modigliani and Miller the theory on capital structure develops following two alternative theoretical approaches: the trade-off theory (from now on, TOT) and the pecking-order theory (from now on, POT).

\subsubsection{The trade-off theory}

According to this theory, there is an optimal indebtedness ratio which depends on the trade-off between the debt's costs and benefits ${ }^{5}$. There are two main categories of costs discussed in the literature: bankruptcy costs and agency costs. Bankruptcy costs depend on the firm's risk of bankruptcy. Unlike the use of its private capital, the use of debt as a mean of financing investments forces the firm to meet fixed obligations in relation to its financers-creditors with regard to the payment of interest and the reimbursement of the capital lent. The risk of bankruptcy, which the firm runs if its cash flow situation should become critical to an extent which jeopardises its compliance with the financial commitments undertaken, generates costs known as bankruptcy costs. When assessing the impact of these costs on the financial structure, it must be remembered that the likelihood that they will occur is directly proportional to the degree of indebtedness of the firm's financial structure itself. In other words, the probability of financial difficulties which, if unresolved, may lead to the firm bankruptcy, is directly proportional to the level of indebtedness. While on the one hand, debt creates costs for the firm relating to the bankruptcy risk, on the other hand it provides benefits deriving from the associated tax shield (Modigliani and Miller, 1963). According to the TOT, the trade-off between the bankruptcy costs and the fiscal benefits deriving from the debt defines the optimal financial structure for the firm. Empirical evidence (Warner, 1977, Altman, 1984 and Graham and Harvey, 2001) tends to confirm the worth of this theoretical approach, highlighting the fact that the firm's decisions in terms of financial structure are based on a comparative analysis of the bankruptcy costs and the benefits in terms of tax savings arising from the use of debt, especially in the case of medium and largesized firms.

\footnotetext{
${ }^{4}$ It has been empirically proven (Fazzari et al., 1988) that the degree of sensitivity to the different forms of financing varies depending on the size of the firm and dividend policies, as well as the duration of the relationship with a specific bank.

${ }^{5}$ It should be remembered that for the purposes of TOT, one benefit considered is that of the taxdeductibility of interest costs. Since this aspect is outside the focus of our study, for more in-depth consideration see the original by Modigliani and Miller, 1963 and then to DeAngelo and Masulis, 1980. For the Italian case see for example Bontempi et al. 2004.
} 
With regard to the validity of the TOT's conclusions, it should be noted that as the firm's level of risk increases, so does the underlying bankruptcy cost, with a negative effect on leverage. Since bankruptcy costs are higher in the case of firms with large amounts of intangible assets, such enterprises are considered riskier and have a lower level of indebtedness than firms with larger amounts of tangible fixed assets. Under this principle, as Jensen and Meckling (1976) suggest, firms with high growth potential - which typically feature large investments in $R \& D$ - should have proportionally less debt than firms in more older sectors ${ }^{6}$. This hypothesis is also supported by the empirical findings relating to Italy: the more mature and traditional sectors are considered safer by creditors (since they have a higher level of fixed assets in relation to investments in R\&D and other intangibles), and all other effects being equal, their degree of indebtedness is, in fact, above average (see Bontempi and Golinelli, 1996 p. 60$)^{7}$.

Hyp. 1 - The TOT explains the existence of a negative relation between leverage and intangible assets.

Similarly, it has been shown that smaller-sized firms are riskier than large ones, so there should be a positive relation between indebtedness and firm size (Ang et al., 1982) ${ }^{8}$.

Hyp. 2 - The TOT explains the existence of a positive relation between leverage and size.

Another aspect of the interdependency between the conclusions to which the TOT leads and the firm's characteristics relates to the firm's profitability. According to the TOT, it would appear that firms with better earnings performances are at an advantage when it comes to the use of debt, since on the one hand they are able to guarantee that the debt will be serviced regularly, and on the other they have greater interest in exploiting the tax benefits involved. However, the empirical evidence points in the opposite direction: highly profitable firms tend to have a low level of indebtedness (see, amongst others, Myers, 1998).

Hyp. 3 - The TOT explains the existence of a positive relation between leverage and profitability.

As well as bankruptcy costs, there are also other costs which may influence the use of debt in the firm's capital structure: agency costs. These costs

\footnotetext{
${ }^{6}$ On this point see, amongst others, also Myers, 1977, Hutchinson and Ray, 1986, and Harris and Raviv, 1990.

${ }^{7}$ However, it should be noted that the empirical evidence on this point is contradictory. For example, Michelas et al., 1999, studying SMEs in the UK, demonstrate a positive relationship between the firm's growth opportunities and indebtedness.

${ }_{8}^{8}$ The empirical evidence is also contradictory with regard to this parameter. Banking theoretical models suggest, for example, that as the firm's size and age increase, it tends to make greater use of differentiated modes of financing (Berger and Udell, 1998).
} 
derive from the conflict of interest between the firm's shareholders, management and financers. Jensen and Meckling (1976) focus their attention on two separate types of conflict of interest: those concerning the relationships between the firm's owners and financers on the one hand, and those concerning the relationship between the firm's owners and management on the other.

On the one hand, shareholders have an interest in realising riskier investment projects because they have a higher expected return than that agreed with the external financers. If the investment is a success, the firm takes the surplus; otherwise, the costs are offloaded onto the financers. This information asymmetry increases the cost of indebtedness, and renders it more expensive than internal finance. As a consequence, firms with high agency costs due to conflicts of interest between owners and financers debt agency costs - should have a lower level of debt financing.

Hyp. 4a - The TOT explains the existence of a negative relation between debt agency costs and leverage.

On the other hand, the management may undertake corporate projects which do not maximise the owners' interest, for the sole purpose of personal gain. In order to prevent opportunistic behaviour of this kind, the owners have to meet costs - capital agency costs - which, unlike debt agency costs, are inversely proportional to the degree of leverage since the obligation to refund capital and pay interest limits the degree of discretion enjoyed by the company's management in its use of the firm's financial resources.

Hyp. 4b - The TOT explains the existence of a positive relation between capital agency costs and leverage.

Therefore, according to the TOT, if we consider the benefits of the use of debt with regard to conflicts of interest between ownership and managers on the one hand, and the higher debt agency costs deriving from high levels of indebtedness on the other, the optimal financial structure will be the one which provides a mix of sources of finance which balances these two phenomena.

Hyp. 4c - According to the TOT, the optimal mix of sources of finance debt and equity - is the outcome of a problem of minimising total agency costs. 


\subsubsection{The pecking-order-theory}

According to the second theoretical approach - POT - it is the presence of the information asymmetries described between owners and financers that implies the existence of a financial hierarchy amongst the sources of finance used by firms. Firms prefer internal sources of finance, or self-financing, and their favourite source of external finance is debt ${ }^{9}$. This apparently also explains why highly profitable companies tend to have low levels of leverage. This financial hierarchy applies in particular to SMEs, which make only limited use of the equity market, even when their legal form allows them to exploit it, because this form of finance is more expensive in terms of information disclosure ${ }^{10}$.

Hyp. 5 - According to the POT, there is a negative relation between the degree of leverage (debt over informed equity) and the level of information asymmetry.

Moreover, the POT also explains why, in contrast with what the TOT predicts, highly profitable companies tend to have low levels of leverage. This is due to the fact that firms which are not particularly profitable have fewer internal funds for new investment projects, meaning that they are forced to use external finance amongst which the firm prefers debt instead of equity.

Hyp. 6 - According to the POT, there is a negative relation between the degree of leverage and the firm's level of profitability.

Corollary 1 - According to the POT, there is a negative relation between the degree of leverage and the firm's level of liquidity.

A simple graph may help us to better understand the problem of the sequential choice of sources of finance ${ }^{11}$. Given the total amount of the investment to be financed (demand for funds, D) and considering the costs associated to the information asymmetries (which define the supply of funds $\mathrm{SF}$ ), the firm will first use self-financing, then debt and as last resort the issue of shares. Let us consider three possible investment projects to be financed, $D_{1}, D_{2}$ and $D_{3}$. If $S F$ refers to the supply of funds and the investment demand is $\mathrm{D}_{1}$ the firm will be able to finance the investment

\footnotetext{
${ }^{9}$ The severity of the information asymmetry implies costs which gradually rise in the transition from selffinancing to banking debt and then equity.

10 The owners of SMEs are generally unwilling to share control of their firms with third parties due to the fear of losing independence, control and flexibility in the management of their businesses. From this point of view, a debt contract is obviously preferable to an equity contract. In the case of a debt contract, the only risk of losing ownership control of the firm is in extreme cases of bankruptcy, although in many cases banks prefer to renew loans before forcing the firm into bankruptcy. For more in-depth discussion see, for example, Holmes and Kent, 1991, Hamilton and Fox, 1998 and Sogorb-Mira, 2005. An analysis of corporate governance and the control of firms in Italy is provided by Bianco and Casavola, 1999.

${ }^{11}$ The analysis which follows is adapted from the work of Fazzari et al., 1988 and Hall, 2002, to which readers should refer for more details.
} 
project entirely with internal funds, and is thus not subject to severe financial constraints. However, if the demand is $\mathrm{D}_{2}$ or $\mathrm{D}_{3}$, the firm will be forced to use external sources, debt and the issue of shares, incurring a cost higher than that of self-financing ${ }^{12}$. The incidence of this cost, which depends on the severity of the information asymmetries between bank and firm and whether or not the firm has access to the banking or capital market, varies from firm to firm, and thus affects investment decisions (see Fig. 1).

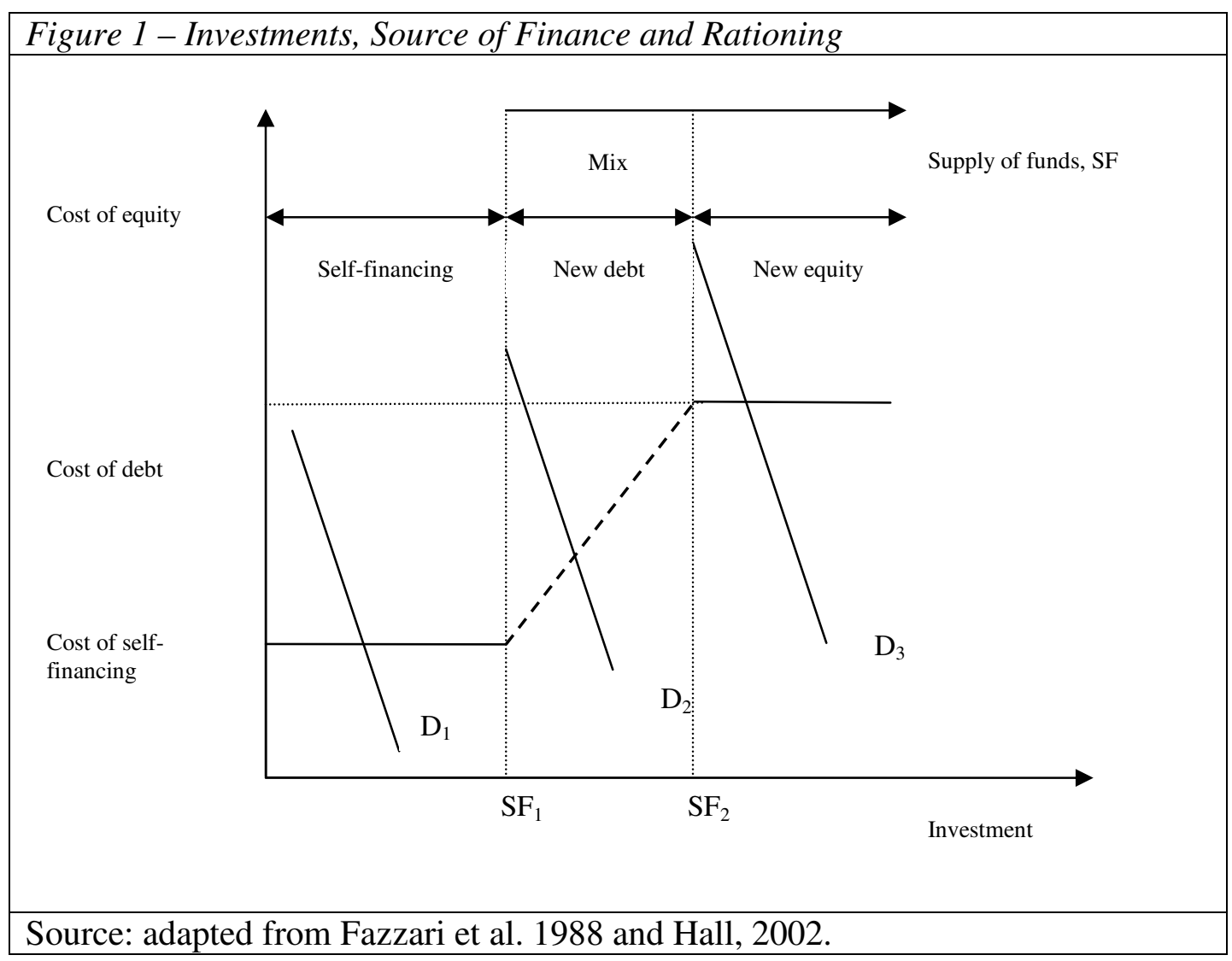

So far, we have considered that the sources of finance used for investment projects depend only on the firm's demand. However, the very market frictions - information asymmetries - which make capital structure choices significant also imply that firms are sometimes rationed by their financers. Therefore, when evaluating decisions concerning sources of finance it is important to include not only the determinants of the demand, but also the parameters which measure the constraints on the supply side (see Faulkender and Petersen, 2006). This becomes particularly important when examining the criteria which guide the choice between the use of equity and debt when external sources of finance have to be used. In the case of equity market over-evaluation, a firm can take advantage from equity issue. Relatively higher-risk investment projects increase this sort of advantage. However, investors pay attention to management equity issuance and underwrite new equity issues if - and only if - the firm has exhausted debt

12 In cases $\mathrm{D}_{2}$ and $\mathrm{D}_{3}$, the project is financed by a mix of sources of finance. In the first case the mix consists of self-financing and debt, and in the second of self-financing, debt and equity. 
financing sources. Thus the investors' attitude forces the firm to adopt a hierarchical strategy in relation to its financial decisions, with self-financing preferred to external resources, and debt viewed more favourably than share issues.

Thus there are two factors which play a crucial role in the choice to use external finance: the level of information asymmetry between the firm and the financial market, and the firm's risk level. Once the hierarchical order of external sources of finance has been decided, with debt preferred to equity, it seems logical to expect that as the firm's level of risk rises, it will become more likely to use the sources of finance at the end of the list. In fact, a high risk rating tends to make the use of debt so expensive that share issues become the preferable option. Each firm has its own debt capacity, strictly dependent on its risk level. Financial decisions also depend on the degree of information asymmetry. Assuming that a firm has a given risk level, the more difficulty the market has in establishing the real value of the firm itself and its_investment projects, the greater the preference for less high-risk sources of finance, and self-financing above all.

Corollary 2 - According to the POT leverage (debt over informed equity) is negatively related to the risk level.

\subsection{Information Asymmetries, Relationship Banking and SMEs}

Like the market, the banking system also assesses a firm's risk rating, which helps to set the risk premium it will be required to pay. However, the presence of adverse selection problems still implies that it is not always possible to "offload" the cost of the information asymmetry onto the cost of the finance (interest rate). In these cases, the bank's screening activity may lead to credit rationing (Stiglitz and Weiss, 1981) ${ }^{13,14}$ and if the company wishes to conclude its investment project it will be forced to issue shares, or to use self-financing if the market rations its credit because it is considered too risky.

While on the one hand the presence of information asymmetries justifies the existence of the banking intermediaries which provide loans even to firms affected by information opacity, on the other hand the screening and monitoring activities ${ }^{15}$ used to assess the firm to be financed expose it to the rationing risk.

Hyp. 7 - The relation between leverage and information opacity is doubtful.

\footnotetext{
${ }^{13}$ Credit rationing is defined as "type I" when some or all clients receive an amount of credit below what they requested at the prevalent interest rate (Jaffee and Russell, 1976). "Type II" rationing occurs when banks refuse credit to some clients while granting it to others identical in all respects to those rationed (Keeton, 1979 and Stiglitz-Weiss, 1981).

${ }^{14}$ Credit rationing can be illustrated in graph form by shifting the debt supply curve upward (see line in bold type in Fig. 1). Thus if the demand were $\mathrm{D}_{2}$ and $\mathrm{D}_{3}$, the financial constraints would become more binding.

${ }^{15}$ In this paper, we concentrate only on the problems related to screening of the firm and/or project to be financed. For a more detailed discussion of monitoring, see, amongst others, Gorton and Winton (2003). For an application to the firm's financial structure see, for example, Kristiansen (2006).
} 
The problems linked to the screening stage derive first of all from the difficulty experienced by subjects outside the company in assessing the profitability of the project financed, as well as the risk of moral hazard during the transmission of the information between the various subjects, with the risk of overestimating good-quality characteristics. In particular, potential investors have difficulty in distinguishing between a "good" quality company which wishes to share the risk of a "good" investment project with third parties (bank or market), and a "poor" quality company which wishes to offload the risk of its investment project onto third parties (Akerlof, 1970). The emission of signals by "good" quality firms is one way of overcoming the problem of selection. Signalling involves costs that can be profitably sustained only by "good" quality firms; doing so enables them to drive the "poor" quality firms off the market and make their investment projects tempting to external investors. Signals involve a form of selfselection on the part of the good-quality supplier. In other words, goodquality firms must undertake an action involving the investment of their private capital in the business they wish to finance, which provides the buyer with a clear indication of the quality of the product on offer, and which is also too expensive to be imitated by the poor-quality producer (Leland and Pyle, 1977).

Hyp. 8 - Leverage is positively to the firm's level of equity (Leland and Pyle, 1977).

Ross (1977), on the other hand, demonstrates that in a context in which bankruptcy is expensive, leverage can be used as a tool for signalling that the firm is of good quality ${ }^{16}$.

Hyp. 9 - A firm's quality is directly proportional to its leverage (Ross, 1977).

Another tool used as a signal for reducing information asymmetries and the risk of rationing is collateral. Bester (1985) demonstrates that in a situation of equilibrium there is no rationing if banks compete by setting both the level of collateral and the interest rate. The firm's choice of one contract rather than another acts as a self-selection mechanism on its part. For example, in exchange for a cut in the interest rate, firms with a low bankruptcy risk are prepared to accept higher collateral than firms with a higher risk ${ }^{17,18}$.

Hyp. 10 - Leverage is in positively related to collateral (Bester, 1985).

\footnotetext{
${ }^{16}$ Ross, 1977 , p. 23 writes "the values of firms will rise with leverage, since, increasing leverage increases the market's perception of value".

17 In contrast with the prevailing literature on collateral, Berger and Udell, 1990 demonstrate that collateral is often associated to higher-risk debtors, higher-risk loans and higher-risk banks.

${ }^{18}$ For a more detailed discussion of signalling theory, see Tirole, 2006, chap. 6.
} 
Once the problem of selecting the project to be financed has been overcome, it becomes necessary to monitor the entrepreneur's behaviour, in order to ensure that his actions and the use of the funds obtained are in line with the stated objective, and no moral hazards (ex-post information asymmetries) arise. This problem can be overcome through: i) the imposition of covenants; ii) the provision of incentives which encourage the agent to behave in the principal's interests; iii) last but not least, verification that the project's economic returns and any profits are distributed in accordance with the ex-ante contract agreements.

In general, the literature on information asymmetries suggests that if the benefits (in terms of the increase in the information produced) deriving from the economies of scale achieved by an intermediary during screening and monitoring operations exceed the costs firms would have to incur to persuade investors to finance them and the costs the investors would have to incur to monitor the firms (Diamond, 1984), it will be economically more beneficial to borrow from the bank than from the market. This reasoning is further reinforced in the case of SMEs, for which the costs of information asymmetries are definitely higher than for large firms.

However, the opportunity for a bank to establish continuous, repeated relationships (relationship lending) generates a mass of exclusive information which allows it to overcome the problems linked to the severity of the information asymmetries, especially with regard to the smallest firms. Relationship lending provides banks with continuos and stable private information. Through repeated interaction with the firm, the bank accumulates soft information which reduces the information asymmetry. There are many theoretical studies ${ }^{19}$ revealing the superiority of this kind of relationship over the more fragmentary, transaction-based type. In the latter, the bank-firm relationship is limited to a single operation, the risk-return evaluation of which is based only on accounting data and information available in the public domain (hard information) ${ }^{20}$.

Naturally, these advantages are further reinforced if the bank is local, with branches in the area in which the borrower firm operates. Naturally, branches in the local community generate undeniable advantages during both screening and monitoring. Greater customers' knowledge, better management of information flows during lending relationships, and more power to control credit risk through the implementation of local sanctions against debtors which are only feasible within a local community, all these factors imply a reduction in SME screening and monitoring costs.

Hyp. 11 - Leverage is in positively related to the duration of relationship lending and the bank's local branches.

This preliminary survey of the theory reveals that, although the financial hierarchy theory suggests that firms prefer self-financing because it is less

\footnotetext{
19 See, amongst others, Berger and Udell, 2002 and DeYoung et al., 2004.

20 Although relationship lending is a mechanism allowing a reduction in the information asymmetries between bank and SME, this does not mean that SMEs may not also benefit from transaction lending. As Berger and Udell (2002) underline, large, non-local banks offer transaction-lending technologies also suitable for use by SMEs (leasing agreements, mortgages, etc.).
} 
expensive in information and economic terms, relationships with local banks may offer advantages which encourage firms to enter into debt contracts even in the absence of binding internal constraints ${ }^{21}$.

The main results discussed in this section can be summarized as shown in Table 1.

Table 1 - Trade-Off Theory versus Pecking-Order Theory

\begin{tabular}{|c|c|c|}
\hline \multirow{2}{*}{ Proxy } & \multicolumn{2}{|c|}{ Expected sign on Leverage } \\
\hline & TOT & POT \\
\hline SIZE & + & - \\
\hline$\overline{A G E}$ & + & - \\
\hline HI-TECH & - & + \\
\hline CASH FLOW & + & - \\
\hline \begin{tabular}{|l} 
PROFITABILITY \\
\end{tabular} & + & $\overline{-}$ \\
\hline INTANGIBLE ASSETS & - & + \\
\hline TANGIBLE ASSETS & + & - \\
\hline AGENCY COSTS & $+/-$ & \\
\hline DEBT AGENCY COSTS & - & - \\
\hline CAPITAL AGENCY COSTS & + & \\
\hline BANKRUPTCY COSTS & - & \\
\hline INFORMATION ASYMMETRIES & & + \\
\hline RATIONING & & $?$ \\
\hline COLLATERAL & & $?$ \\
\hline LEVERAGE & & $?$ \\
\hline LOCAL BANK & & + \\
\hline DURATION & & + \\
\hline
\end{tabular}

Source: adapted from Bontempi (2002), Di Majo et al. (2005) and Huang e Song (2006).

\section{Description of the Sample}

The database used for this study is the Survey of Italian Firms conducted by the SME Observatory run by the Capitalia Research Division. The survey is one of the main sources of information on the Italian business system, and is based on data obtained through the submission of questionnaires to firms. The survey is carried out on a sample basis for firms employing from 11 to 500 employees, and becomes a full census for firms with more than 500. The accounting data source was then integrated with the AIDA - van Dijk Bureau database, which completes the financial statement data for Italian firms considered in the Survey and provides greater historic depth in the accounting data used.

The database consists of qualitative and quantitative data on 4,289 firms, of which 3,801 employ fewer than 250 employees and 3,385 declared that they had made investments during 2001-2003; this last group makes up the database for our survey. The most significant information for our purposes refers to the sections of the questionnaire ${ }^{22}$ focusing on investments and

\footnotetext{
21 Naturally, there may also be intermediate solutions in which the firm opts for a mix of sources of finance: self-financing, debt and, in some cases, equity. For more discussion of this point see, amongst others, Repullo and Suarez, 1998 and Bolton and Freixas, 2000.

22 It should be remembered that we are dealing with a questionnaire, and so the data provided are affected by the compiler's convictions as to how the reported event should be defined.
} 
sources of finance $e^{23,24}$. These sections ask the firm interviewed to provide a percentage breakdown of the use of the different financing channels ${ }^{25}$ used to finance investments ${ }^{26}$.

The aim of our study is to analyse both the decision to use self-financing as an alternative to external sources of finance to cover investment expenditure, and the level of use of self-financing if it is not the only source of finance used (mix of sources of finance). The empirical study, therefore, concentrates on the determinants of the decision to use self-financing, and once this decision has been taken, on the extent to which this tool is used (as a complementary or exclusive source). The explanatory variables (see Tab. 5) used here relate: i) to the firm's structural characteristics (age, size, etc.); ii) to the size of the information asymmetries; iii) to the structure of the credit market and its relationship with the firm.

In order to identify the dependent variables used in this study (see Tab. 5), we first of all used the information on self-financing obtained from the Capitalia Survey questionnaire ${ }^{27}$. We also reprocessed these data by combining them with quantitative information obtained from AIDA.

Specifically, the dependent variables are: Selffin_A which assumes the value 1 if self-financing is greater than zero and is otherwise 0, Selffin_B which assumes the value of 1 if self-financing is greater than $50 \%$ and is otherwise 0 , and Selffin_C which assumes the value of 1 only if self-financing is equal to $100 \%$ and is otherwise 0 .

The questionnaire also allows exact definition of the percentage of selffinancing used to finance the investments, Selffin_\%. Multiplying this value by the total investments for 2001-2003 produces the variable Selffin_lev which expresses the value in Euros of the investments self-financing during the period surveyed. Finally, we calculated the variable Selffin_Rate i.e. the ratio of Selffin_lev to total assets.

The statistics describing the relative distribution of the proportion of selffinancing of investments (Selffin_\% and Selffin_lev) show a strong concentration on the extreme values, suggesting a tendency to self-selection processes with regard to the decision as to whether or not to use self-

\footnotetext{
${ }^{23}$ Section C - "Investment, Technological Innovation and Research and Development". In particular, Question C1.5: "How were the investments made during 2001-2003 financed?" (see Capitalia, 2005).

${ }^{24}$ The possible choices refer to the use of private capital and self-financing. The level of use of private capital as a method of financing appears to be negligible, while leasing, and above all bank debt, are a significant alternative to self-financing.

${ }^{25}$ Therefore, the reply does not define the structure of the total sources of finance used by the firm over time, which can presumably be obtained as stock figures in the Statement of Assets and Liabilities, but rather gives the breakdown of the sources of finance used within the period considered to support the investments made. Moreover, it must be noted that an analysis of the variations in the debt ratio over a given period does not allow a separate analysis of the loan and repayment operations, since the variation provides the overall balance of these operations. Use of the question included in the questionnaire has the advantage that it is unaffected by any repayment operations during the period, which on the other hand might have an impact on the debt ratio. When it comes to representing decisions, the questionnaire is more sensitive than the book figures available in the Statement of Asset and Liabilities to the firm's own perception of the event described. On the one hand, this may lead to distortion due to the survey technique, but on the other it places more emphasis on the behavioural aspect with regard to the entrepreneur's choice of sources of finance. See Li and Prabhala, 2006.

${ }^{26}$ Note that the Investments heading on which our subsequent analysis will focus includes all tangible and intangible investments except for expenditure on $R \& D$. For a study on the diversification of sources of financing for R\&D expenditure, see Brighi and Torluccio, 2006.

${ }^{27}$ See section C1.5, see Capitalia, 2005.
} 
financing. The sample shows a strong imbalance in the direction of small firms (see Tab. 1). 50\% (75\%) of firms have total assets of less than 8.8 (18.7) million Euros and employ fewer than 56 (123) employees. In view of the size factor, the type of firm under consideration does not usually make significant use of equity ${ }^{28}$, and this is in fact marginal in relation to the investment financing operations of the Italian SMEs covered by our study.

\section{The determinants of the optimal mix of sources of finance}

As the theoretical literature suggests, the role of self-financing is significant in both TOT and POT.

According to the TOT the firm's financial investment structure is based on the cost-opportunity ratio between internal and external rescources.

According to the POT firms finance their projects using a combination of self-financing, debt and equity, in line with a rise in information asymmetries and financing costs (see Fig. 1).

Moreover as suggested in the previous sections there are also banking factors like relationship lending and credit market structure that can influense the choice of the mix of sources of finance by a firm.

From the empirical point of view, we therefore need to measure the mix of sources of finance, in terms first, of the combination of self-financing and external resources, in relation to the availability and cost-opportunity ratio of internal and external resources and, then, of the structure of the credit market. To achieve this, as already outlined in the previous points, the focus of the empirical study was placed on the questions within the questionnaire which provide the basis for analysing both the decision to use self-financing and the proportion of the financial need generated by the investments made which is actually covered by this source of finance.

The study's emphasis is thus on the means by which investments are financed and not on the firm's financial structures in the sense of ratio between debts and equity, as set out in the Statement of Assets and Liabilities $^{29}$. In other words, we do not study the effects of a new investment on the stock of debt and equity in a firm's financial statement, but rather the percentage of use of self-financing (compared to debt and equity) in the investment operations carried out during the three-year period investigated.

The descriptive statistics in Tables 3-5 enable us to make several preliminary comments with regard to the effects of the firm's structural and financial characteristics on the way in which investments are financed.

${ }^{28}$ Even if it were to be used, in view of the small size of the firms, it could be considered as equivalent to self-financing since generally the share capital is provided direction by the shareholders, who are "informed" about the firm's risk and profitability characteristics. Thus the empirical results would not change if we were to expand our definition of self-financing to include equity.

${ }^{29}$ It should be noted that the financial payables heading has special features which vary depending on whether financial statements are presented in full or short form. On this point see, for example, Cenni Salotti (2006). 
Tab. 3 shows that on average self-financing, as either principal (Selffin_B) or exclusive (Selffin_C) form of finance, tends to be the favourite choice of the youngest firms. With regard to the size variable, self-financing as unique form of finance (Selffin_C) tends on average to be more common amongst the smallest firms: $29.27 \%$ of firms with total assets of less than 5 million Euros self-finance $100 \%$ of their investments, compared with $26.34 \%$ (24.81\%) of firms with total assets between 5 and 15 million Euros (over 15 million Euros).

Tab. 3 reveals that, on average, firms which decide to finance their investments $100 \%$ through the use of internal funds have an investment ratio, defined as ratio between investments and total assets, lower (mean $2.81 \%$ ) than firms which also use other sources of finance (means $3.52 \%$ and $4.07 \%$ respectively). Which means to say that if the investment ratio is low - because investments are small in relation to total assets - the firm will self-finance $100 \%$ of its investments. As the size of the investment to be made gradually rises, internal resources are no longer sufficient to cover all the expense, and the company is forced to use external sources of finance (see Fig. 1) ${ }^{30}$. The cash flow variable does not "significantly" affect the degree of self-financing, since its values are virtually identical for Selffin_A, Selffin_B and Selffin_C. On the other hand, as was to be expected, cash flows are higher if the firm has decided to use self-financing than in the opposite case. In other words, the availability of cash flows signals a capacity for self-financing, and is thus an initial factor of selfselection for firms.

Tab. 4 summarises the effects of "internal" and "external rationing" on the ways in which investments are financed. As the literature indicates, the decision to use self-financing may sometimes be simply the consequence of forms of external rationing. In order to better investigate the causes of the use of self-financing, we compare the possible inadequacy of internal resources to cover investments (internal rationing) ${ }^{31}$ with the level of rationing reported in the questionnaire (external rationing) ${ }^{32}$. For example, if we consider the group where self-financing is the main but not the only source of finance (Selffin_B), we find that $54.30 \%$ of firms, although subject to external rationing and although they had sufficient funds to finance $100 \%$ of their investments internally, did not choose this option. This may indicate that, although the firm had the funds to finance its own investments, it preferred not to gamble on the entire project, either partially or in full. The failure to provide signalling through self-financing forces the bank to apply at least partial rationing ${ }^{33}$ with the consequence that the investment is carried through, but on a smaller scale than in the initial plan.

\footnotetext{
30 All other conditions being equal, in the transition from D1 to D2 in order to finance the investment project the firm is forced to request funds from external sources; otherwise, it is unable to carry out its plan.

31 Internal rationing occurs when a firm is unable to cover its investment requirement rapidly with internal funds. The variable used as proxy for this inability is the ratio between the firm's cash flows in the previous period (source AIDA) and the size of the investments reported (see Capitalia).

32 Questionnaire Section F - Question F1.5: "In 2003, would the firm have liked to have obtained more credit at the interest rate agreed with the bank?" (see Capitalia, 2005).

33 Partial rationing may be explained by the presence/absence of suitable collateral.
} 
The other $45.70 \%$ of firms rationed by the banks did not use self-financing, because their internal resources were insufficient.

Last but not least, if we concentrate solely on the effects of internal rationing on the ways in which investment operations are self-financed (see last column, Tab. 4), we find that even with cash flows high enough to support the investment operation, firms may decide not to finance their projects. This implies, in other words, that firms do not see the use of internal sources as top priority, as envisaged by POT. There may be other reasons for which a simple cost-benefits analysis using the TOT approach may lead firms to prefer external to internal financing, a phenomenon which may become particularly significant in periods when interest levels are low, for example.

The aim of the following points is to identify, both separately (point 4.1) and jointly (point 4.2), the variables which lead on the one hand to the "decision" 34 as to whether or not to use self-financing, and on the other hand the "degree" 35 of self-financing within the mix of sources of finance once the firm has stated that it does finance its own investments.

\subsection{The financing of investments: the multivariate study}

The multivariate analysis which follows aims to estimate the probability of self-financing using logit regressions (models 1-3) and to estimate the "importance" of self-financing by means of a simple, intuitive OLS estimate (models 4-5) (see Tab. 7).

The Total Assets variable - used as proxy for the firm's size- has a positive, statistically significant effect in models 1,2 and 4. As size increases so does the propensity to use self-financing, although not as the only source of funds (model 3). In other words, as the firm's size increase so does its ability to finance itself, but the same is true of the other sources of finance. This appears to explain why the variable is not significant in model 3. The same reason might explain why it is significant with regard to the Selffin_\% variable - which simply measures the extent of self-financing in percentage terms compared to other sources of finance - but loses significance when measured with regard to the Self-financing Rate variable, which measures the level of coverage of investments by means of self-financing in relation to total assets. In other words, as size increases, the proportion of selffinancing used to cover investments in relation to total assets decreases. According to information asymmetry studies, membership of HI-Tech sectors requires a certain degree of self-financing, although this is not necessarily the only source of funds. In fact, the HI-Tech variable is only significant in models 1 and 2 and not in model 3. HI-Tech firms have a greater propensity to self-financing in percentage terms compared to the other sources of finance (model 4), but not in relative terms in proportion to the firm's total assets (model 5).

\footnotetext{
34 Dichotomic variables: Selffin_A, Selffin_B and Selffin_C. see Tab. 6.

${ }^{35}$ Degree of self-financing of investments defined as (Amount of investments covered by self-financing * Investments in Euros) / Total assets, see Tab.6.
} 
The Group variable (a dummy which assumes the value 1 if the firm belongs to a group) has a positive effect on self-financing in its various forms (models 1-5), but in no case is it statistically significant. The Age of firm variable has a positive influence on self-financing in its various forms (models 1-5) but is only statistically significant in model 5 .

An increase in Leverage goes hand-in-hand with less use of self-financing: this reverse proportionality is statistically significant in all the models.

Firms which are completely self-financing (model 3) generally have adequate financial resources (Current Ratio, Cash Flow and Net Cash Flows), and since they do not use external sources or bank debt, they are $100 \%$ self-financing. As was to be expected, the Current Ratio variable shows a positive relationship to self-financing. As Current Ratio increases, there is a statistically significant rise in the probability that the firm investments will be $100 \%$ self-financed. Moreover, Current Ratio has a statistically significant influence on the percentage level of self-financing compared to the other sources of finance (model 4), but not on the level of self-financing as a proportion of the firm's total assets (model 5). Cash flows (i.e. the ratio between cash flows and total assets) have a significant negative impact on the tendency to be fully self-financing (model 3). On the one hand, this finding supports the TOT hypothesis, by which high cash flows make external sources of finance less expensive, but on the other this result appears to conflict with the POT, which would lead us to expect a positive sign, supporting the chronological preference for internal resources. However, this finding is confirmed by the statistically significant positive sign of the estimate in model 5.

The Net Cash Flows variable (a dummy variable which assumes the value 1 if the cash flows for the previous periods exceed investments) is a more effective measurement of the real capability for self-financing investment projects, even without recourse to any external finance. In this case the exclusive use of internal sources is clearly prevalent, as indicated by the positive value of the coefficient estimated for the category variable in the models in all 5 models.

The time priority of internal capital funding, especially in the most intensive interpretation given by model 3 and proportionally in model 4 , is also supported by the presence of accounting parameters linked to the firm's performance during previous years $(R O S)$, the variability in operating profit and ROI $\left(S D \_R O \text { and } S D \_R O I\right)^{36}$.

As expected, the Investment Rate variable, the main variable for the demand for finance, has a negative sign in models 2,3 , and 4 .

The literature gives relationship lending an important role in the financing of SMEs. From an empirical point of view, the variables which best approximate the lending relationships between bank and firm are: i) the number of banks from which the firm borrows; ii) the proportion of its debt provided by main bank; iii) the functional distance between the bank and

36 The variation in operating profit and ROI provide a proxy for firms' risk levels. In line with the TOT, they have a positive impact on the availability of funds for self-financing, since higher risk makes external sources of finance more expensive. 
the firm, and iv) credit rationing. As the number of banking relationships (Number of banks) increases and the proportion of debt with the main bank (Main bank share) increases, self-financing decreases. These findings are statistically significant with regard to the decision to use only self-financing to cover investments (model 3) or to make partial use of self-financing (models 1-2), as well as for the percentage use of self-financing in relation to other sources (model 4), but not with regard to the degree of coverage of investments by means of self-financing in relation to total assets (model 5). Functional nearness (Local main bank) has a positive effect on selffinancing but is only significant with regard to the decision to use only selffinancing (model 3) and the proportion of self-financing within all sources of finance (model 4). With regard to credit rationing, the empirical evidence suggests that firms which believe they are suffering from rationing are less able to finance themselves. The relationship is always statistically significant except in model 3. This suggests an order of preference, in which firms which use only self-financing (model 3) are not concerned about rationing. This is compatible with the POT (see Fig. 1), under which firms prefer to finance all investments with internal resources, and when this is not possible, they reduce their level of self-financing (model 1 and 2) and apply for external finance, which may be rationable.

In contrast with the suggestions of the theoretical literature on information asymmetries, the Information Opacity variable, measured as the ratio between tangible and intangible fixed assets, does not seem to produce even weakly significant results on the decision to finance investments using internal sources (models 1-3), and certainly has no effect on the weight of self-financing amongst the sources of finance used (models 4-5).

The Tangible fixed assets variable, used as proxy for collateral, is only statistically significant in models 3 and 5, and even here the signs are contradictory. The negative sign of the estimate for model 3 is in line with the literature on collateral, which suggests that firms with a high degree of tangible fixed assets find it easier to obtain external finance - mainly debt. However, this finding is not confirmed by model 5, which would appear to suggest the exact opposite.

Last but not least, the variables relating to the structure of the credit market do not seem to have a statistically significant effect on the financing decision (models 1-3) or on the breakdown of the sources of finance (models 4-5), except for the HHI_loans variable, which has a statistically significant negative sign with regard to firms' decision to use $100 \%$ selffinancing (model 3).

\subsection{The financing of investments: Heckman two-stage analysis (preliminary)}

The use of different models in order to attempt to identify the determinants of financing decisions (models 1-3) on the one hand, and the breakdown of the sources of finance used (models 4 and 5) on the other, produced 
sometimes conflicting results, making further investigation necessary. The analysis provided in this section uses a specification which considers the stages of the selection and composition of the mix of sources of finance simultaneously, using the well-known sample self-selection model first proposed by Heckman (1979) ${ }^{37}$ (see Tab. 8). Although simple, the model suggested provides a significant separation between the stage of (self)selection and the stage of the composition of the mix of sources of finance, highlighting the need to study this problem using a two-stage method ${ }^{38,39}$. The variables which measure the internal capacity to generate cash flows, the capacity of these cash flows to finance the investments internally, the presence of rationing and the firm's financial structure were included in the "selection" stage as regressors. All the variables were statistically significant and had the expected sign ${ }^{40}$. The negative sign of rationing on self-financing in the selection stage supports a POT hypothesis, in which firms with fewer internal funds, i.e. those which use less self-financing, come up against problems of bank rationing. During "specification" of sources of finance, the firms which have already decided to self-financing their investments decide the degree of self-financing to use on the basis of the internal resources available, ignoring rationing problems and assigning little importance to relationship and information variables, but making use of the large number of bank relationships at their disposal and the degree of concentration of the credit market. Moreover, amongst the firms which have decided to self-financing, the largest show higher rates of self-financing of investments, as do those belonging to $\mathrm{Hi}-\mathrm{Tech}$ sectors. The profitability variables (ROS and ROI) have a positive effect on the increase of internal capital. When rates of investment are high, firms plan to use a higher proportion of internal financial resources to finance their projects. Moreover, the amount of self-financing allocated to investments (dependent variable of the model) is reversely proportional to the degree of $R \& D$ and the cash flows net of $R \& D$ expenditure. In other words, there is competition between these two alternative forms of investment.

\footnotetext{
37 Heckman's model (1979), which belongs to the general category of selection models, is used in corporate finance to discuss self-selection phenomena. Here, it is important not to consider the selection aspect as a sampling error requiring correction or elimination, but rather to identify the reasons underlying the selection, in terms of unobservable private information, and then represent the specification of the parameter to be studied (e.g. degree of self-financing). The idea is that the degree of self-financing is only observable for those who have decided to use this method (first-stage selection). The second stage therefore models the percentage of financing, provided self-financing has taken place. Heckman's model is preferable to a Tobit model because the latter uses the same variables during both selection and specification. It thus becomes difficult to separate the variables linked to the decision to self-financing from the variables which determine the composition of the finance used.

${ }^{38}$ Ex-ante self-selection is also a signalling tool useful for obtaining external funds. On sources of finance and signalling, see for example Hellman and Stiglitz, 2000.

${ }^{39}$ From the statistical point of view, the reliability of the joint estimate of the source of finance selection stage and the source of finance composition stage when a selection model is used with our data-set is confirmed by the significance of the Mills ratio. See Tab. 8 .

${ }^{40}$ In other specifications, the presence of bank relationship variables in the selection stage leads to the non-significance of the joint estimate. In other words, relationship variables are not as significant as rationing. The other specifications have been omitted for reasons of space, but are available from the authors on request.
} 


\section{Conclusions}

The theoretical survey conducted as part of this study reveals that, although the financial hierarchy theory suggests that firms prefer self-financing, because it is less expensive in economic terms, relationships with local banks may offer advantages which encourage firms to enter into debt contracts even in the absence of binding internal constraints. Moreover, there may also be intermediate solutions in which the firm opts for a mix of sources of finance: self-financing, debt and, in some cases, equity. The failure of theory to provide definitive results encouraged us to conduct an empirical investigation to determine which theoretical model - TOT and/or POT - better explains the behaviour of Italian SMEs in their investment financing decisions, and which variables explain these decisions and the diversification of the sources of finance used. The empirical study focused in particular on the role of self-financing as an alternative to external sources. In order to measure the decision to use self-financing and the subsequent composition of the financing mix, we used different techniques, first independent models and then a self-selection model. The first results, in line with POT, confirm an approach comprising an initial check on the availability of internal resources, followed if necessary by the use of external capital, including bank debt. The rationing component, which here unusually shows a reduction in internal capital, further reinforces the POT hypothesis, highlighting that use of bank capital is an option used only when insufficient internal funds are available. The decision to use self-financing as the first option confirms that firms are affected by information asymmetries, implying that external funds are more expensive than internal funds. Soft and hard forms of information have no significant effect on the mix chosen after the decision to use self-financing. Internal liquidity and membership in Hi-Tech sector are positively correlated with the use of internal resources. However, in order to reach definitive conclusions, it is advisable to investigate how the information components are explicitly linked to the rationing decision, and thus whether the rationing itself is simply the synthesis of severe information barriers which affect the costsbenefits of the capital and may thus support the alternative hypothesis of TOT.

\section{References}

Altman, E.I., "A Further Empirical Investigation of the Bankruptcy Cost Question”, Journal of Finance, Vol. 39, n. 4, 1067-1089, 1984

Akerlof, G., "The Market for 'Lemons': Qualitative Uncertainty and the Market Mechanism", Quarterly Journal of Economics, 84 (3), 488-500, 1970

Ang, J.S., Chua, J.H. e McConnell, J.J., "The Administrative Costs of Corporate Bankruptcy: A Note", Journal of Finance, n. 37, pp. 219-226, 1982

Berger, A.N. and G.F. Udell, "Collateral, Loan Quality, and Bank Risk", Journal of Monetary Economics, 25, 21-42, 1990 
Berger, A. N. and G. F. Udell, "The economics of small business finance: The roles of private equity and debt markets in the financial growth cycle", Journal of Banking \& Finance, 22(6-8), August: 613-673, 1998

Berger, A.N. and Udell, G.F., "Small business credit availability and relationship lending the importance of bank organisational structure", Economic Journal 112(2002), 32-53

Bester, H., "Screening vs. Rationing in Credit Markets with Imperfect Information", American Economic Review, 75, 850-855, 1985.

Bianco M., and P. Casavola, "Italian Corporate Governance: Effects on Financial Structure and Firm Performance", in European Economic Review, n. 43, pp. 1057-1069, 1999

Bolton, P. and Freixas, X. Equity, "Bonds, and Bank Debt: Capital Structure and Financial Market Equilibrium under Asymmetric Information", Journal of Political Economy 108, 324-351, 2000

Bontempi, M.E. and R. Golinelli, "Le determinanti del leverage delle imprese: una applicazione empirica ai settori industriali dell'economia italiana", Studi e Note di Economia, n.2/96, pp. 35-66, 1996

Bontempi, M.E., S. Giannini and R. Golinelli, "Corporate tax reforms and financial choices: an empirical analysis", mimeo, Dipartimento di Economia, Università di Ferrara, 2004

Brealey, R.A., S. C. Myers and S. Sandri, "Principi di finanza aziendale"McGraw-Hill Libri Italia, Milano, 2003

Brighi P. and G. Torluccio, "Il ruolo dell' autofinanziamento nell' attività di investimento e di R\&S", mimeo, Università di Bologna, 2006

Capitalia, "Osservatorio sulle Piccole e Medie Imprese. Indagine sulle imprese italiane", Roma, ottobre, 2005

Cenni S. and V. Salotti, "Avere o non avere debiti con le banche? Le PMI manifatturiere italiane e il ricorso al credito bancario", Atti del convegno AIDEA, 2006

Corigliano R., "Corporate banking, credito e finanza delle imprese", Bancaria editrice, Roma, 2006

De Angelo H. and Masulis R. W., "Optimal capital structure under corporate and personal taxation", Journal of Financial Economics, v. 8, n. 1, pp. 3-29, 1980

de Meza, D. and Webb D.C., "Too Much Investment: A Problem of Asymmetric Information”, Quarterly Journal of Economics 102, 281-292, 1987

Diamond, D. W., "Financial Intermediation and Delegated Monitoring", Review of Economic Studies, 51, 393-414, 1984

Fama, E. and K. French, "The Cross-Section of Expected Stock Returns", Journal of Finance, 47/2, 427-465, 1992

Faulkender, M. and M.A. Petersen, "Does the Souce of Capital Affect Capital Structure", The Review of Financial Studies, v. 19, n. 1, pp. 45-79, 2006

Fazzari, S.M., R.G. Hubbard and B.C. Petersen, "Financing Constraints and Corporate Investment", Brooking Papers on Economic Activity, Vol. 1988, No. 1, 141-2006, 1988 
Frank M. Z. and V. K. Goyal, "Trade-off and Pecking Order Theories of Debt", Working Paper, Center for Corporate Governance - Tuck School of Business at Dartmouth, 2005

Gorton, G. and Winton, A., "Financial Intermediation", in G. Constantinides, M. Harris and R. Stulz, eds., Handbook of the Economics of Finance, Amsterdam: North-Holland, 2003

John R. Graham and Campbell R. Harvey, The theory and practice of corporate finance: evidence from the field Journal of Financial Economics Volume 60, Issues 2-3, May 2001, Pages 187-243

Hall, B.H., "The Financing of Research and Development", Oxford Review of Economic Policy, Vol. 18, no. 1, 2002

Hamilton, R. T. and M. A. Fox, , "The Financing Preferences of Small Firm Owners", International Journal of Entrepreneurial Behaviour \& Research 4(3), 239-248, 1998

Heckman, J.J., "Sample selection as a specification error", Econometrica, 47, 153-161, 1979

Harris, M. and Raviv, A. "Capital Structure and the Informational Role of Debt," Journal of Finance 45, 2, pp. 321-49, June 1990

Hellmann T. and Stiglitz, J.E., "Credit and equity rationing in markets with adverse selection", European Economic Review 44, 281-304, 2000

Holmes, S. and P. Kent, "An empirical analysis of the financial structure of small and large Australian manufacturing enterprises", The Journal of Small Business Finance 1(2), 141-154, 1991

Hutchinson, P. and Ray, G. 1986, 'Surviving the Financial Stress of Small Enterprise Growth', in The Survival of the Small Firm. Volume 1: The Economics of Survival and Entrepreneurship, eds J. Curran J., Stanworth and D. Watkins, Gower Publishing, Aldershot, England, pp. 53-71.

Jaffee, D.M. and T. Russell, "Imperfect Information, Uncertainty, and Credit Rationing", The Quarterly Journal of Economics, Vol. 90, No. 4, pp. 651-666, Nov. 1976

Jensen, M.C. and W.H. Meckling,. "Theory of the firm: managerial behavior, agency costs and ownership structure", Journal of Financial Economics 3, 305-360. 1976

Keeton, W.R., "Equilibrium Credit Rationing", New York: Garland, 1979 Kristiansen, E.G., "Strategic Bank Monitoring and Firms' Debt Structure", mimeo, 2006

Leland, H. E. and D.H. Pyle, "Informational Asymmetries, Financial Structure, and Financial Intermediation", The Journal of Finance, Vol. XXXII, n. 2, 371-387, 1977

Landier, A., "Financial institutions and entrepreneurship: Banks vs. Venture Capitalists", mimeo, MIT, 2002

Li, K. and Prabhala, N. R., "Self-Selection Models in Corporate Finance", Working Paper, Center for Corporate Governance - Tuck School of Business at Dartmouth, 2006

Michaelas, N.; Chittenden, F. and Poutziouris, P., "Financial policy and capital structure choice in UK SMEs: empirical evidence from company panel data", Small Business Economics, 12, 113-130, 1999 
Modigliani, F. and Miller, M.H., "The cost of capital, corporation finance, and the theory of investment", American Economic Review 48, 261-297, 1958

Modigliani F. and Miller M. H., "Corporate income taxes and the cost of capital: a correction", American Economic Review, giugno, v. 53, n. 3, pp. 433-443, 1963

Myers, S.C., "The capital structure puzzle". Journal of Finance 39, 575592. 1984.

Myers, S. C., "Still Searching for Optimal Capital Structure", in J. M. Stern, D.H. Chew Jr, The Revolution in Corporate Finance, Blackwell Publishers Ltd, 1998, pp. 121-122.

Myers, S.C. and Majluf, N., "Corporate financing and investment decisions when firms have information that investors do not have", Journal of Financial Economics 13, 187-221. 1984.

Repullo, R. and J. Suarez, "Monitoring, Liquidation, and Security Design", The Review of Financial Studies Vol. 11, No. 1, pp. 163-187, Spring 1998

Ross, S. A., "The Determination of Financial Structure: The incentive signalling approach", Bell Journal of Economics, Vol. 8, No. 1 pp. 23-40, Spring, 1977

Schäfer, D. A. Werwatz and V. Zimmermann "The Determinants of Debt and (Private-) Equity Financing in Young Innovative SMEs: Evidence from Germany", DIW Berlin German Institute for Economic Research Working Paper n. 411, March 2004

Sogorb-Mira, S., "How SME Uniqueness Affects Capital Structure: Evidence From A 1994-1998 Spanish Data Panel", Small Business Economics, 25, 447-457, 2005

Stiglitz, J. and Weiss, A., "Credit Rationing in Markets with Imperfect Information", American Economic Review 69, 2, Maggio, 339-345, 1981

Tirole, J. "The Theory of Corporate Finance", Princeton University Press, 2006

Ueda, M., "Banks versus Venture Capital: Project Evaluation, Screening, and Expropriation", The Journal of Finance Volume 59, pp. 601-621, 2004 Warner, J.B., "Bankruptcy Costs: some Evidence", Journal of Finance, Vol. 32, n. 2, 337-347, 1977

Weston, J.F., "Toward Theories of Financial Policy", The Journal of Finance, Vol. 10, No. 2, 130-143, 1955 


\section{Statistical Appendix}

Table 2 -Dimensional characteristics of the companies in the sample

\begin{tabular}{|l|ccccccc|}
\cline { 2 - 8 } \multicolumn{1}{c|}{} & Mean & Std Dev & P 05 & P 25 & Median & P 75 & P 95 \\
\hline Employees (num.) & 106 & 131 & 13 & 25 & 56 & 123 & 402 \\
Total Assets 2003 (x 1000) & 29839 & 158256 & 1317 & 3704 & 8840 & 18743 & 105207 \\
Total Turnover 2003 (x 1000) & 29962 & 131956 & 1559 & 4152 & 9638 & 20884 & 100086 \\
\hline
\end{tabular}

Table 3 - Structural characteristics of the firm and self-financing

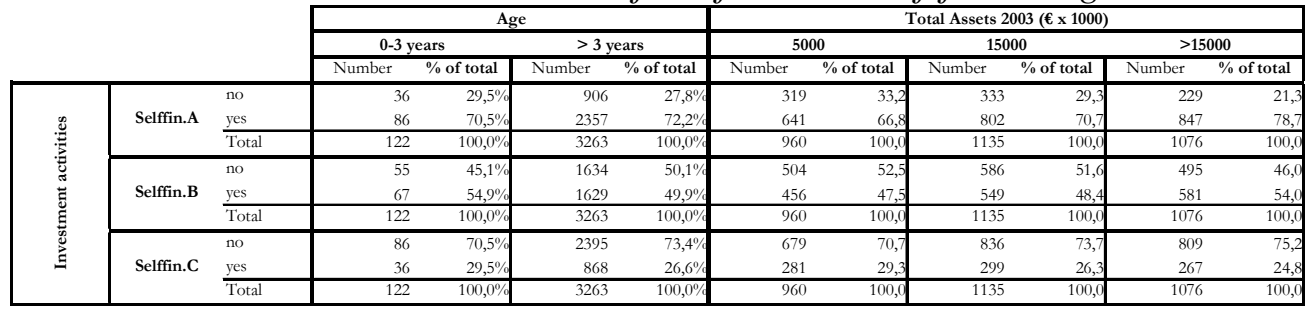

Table 4 - Investments, cash flows and self-financing

\begin{tabular}{|c|c|c|c|c|c|c|c|}
\hline & & \multirow[b]{2}{*}{ Number } & \multirow[b]{2}{*}{ Perc. } & \multicolumn{3}{|c|}{ Investment Ratio } \\
\hline & & & & & Mean & Std Dev & Median \\
\hline \multirow{9}{*}{ 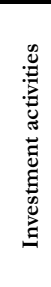 } & \multirow{3}{*}{ Selffin.A } & no & 942 & $27,8 \%$ & $3,9 \%$ & $4,6 \%$ & $2,5 \%$ \\
\hline & & yes & 2443 & $72,2 \%$ & $4,1 \%$ & $9,3 \%$ & $2,4 \%$ \\
\hline & & Total & 3385 & $100,0 \%$ & $4,0 \%$ & $8,3 \%$ & $2,4 \%$ \\
\hline & \multirow{3}{*}{ Selffin. B } & no & 1689 & $49,9 \%$ & $4,5 \%$ & $8,2 \%$ & $2,9 \%$ \\
\hline & & yes & 1696 & $50,1 \%$ & $3,5 \%$ & $8,3 \%$ & $2,1 \%$ \\
\hline & & Total & 3385 & $100,0 \%$ & $4,0 \%$ & $8,3 \%$ & $2,4 \%$ \\
\hline & \multirow{3}{*}{ Selffin. C } & no & 2481 & $73,3 \%$ & $4,5 \%$ & $7,2 \%$ & $2,9 \%$ \\
\hline & & yes & 904 & $26,7 \%$ & $2,8 \%$ & $10,6 \%$ & $1,4 \%$ \\
\hline & & Total & 3385 & $100,0 \%$ & $4,0 \%$ & $8,3 \%$ & $2,4 \%$ \\
\hline
\end{tabular}

Table 5 - The choice of self-financing: "internal" and "external" rationing

\begin{tabular}{|c|c|c|c|c|c|c|c|c|}
\hline & & & \multicolumn{6}{|c|}{ Rationing } \\
\hline & & & \multicolumn{2}{|c|}{ yes } & \multicolumn{2}{|c|}{ no } & \multicolumn{2}{|c|}{ Total } \\
\hline & & & $\mathrm{CF}<\mathrm{INV}$ & $\mathrm{CF}>\mathrm{INV}$ & CF $<$ INV & $\mathrm{CF}>\mathrm{INV}$ & $\mathrm{CF}<\mathrm{INV}$ & CF> INV \\
\hline \multirow{9}{*}{ 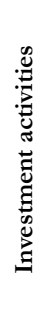 } & & no & $44,1 \%$ & $55,9 \%$ & $30,0 \%$ & $70,0 \%$ & $32,7 \%$ & $67,3 \%$ \\
\hline & Selffin.A & yes & $37,8 \%$ & $62,2 \%$ & $21,4 \%$ & $78,6 \%$ & $23,5 \%$ & $76,5 \%$ \\
\hline & & Total & $40,2 \%$ & $59,8 \%$ & $23,7 \%$ & $76,3 \%$ & $26,0 \%$ & $74,0^{\circ}$ \\
\hline & & no & $45,7 \%$ & $54,3 \%$ & $30,9 \%$ & $69,1 \%$ & $33,5 \%$ & $66,5^{\circ}$ \\
\hline & Selffin.B & yes & $31,3 \%$ & $68,7 \%$ & $17,0 \%$ & $83,0 \%$ & $18,5 \%$ & $81,5 \%$ \\
\hline & & Total & $40,2 \%$ & $59,8 \%$ & $23,7 \%$ & $76,3 \%$ & $26,0 \%$ & $74,0^{\circ}$ \\
\hline & & no & $42,9 \%$ & $57,1 \%$ & $26,6 \%$ & $73,4 \%$ & $29,1 \%$ & $70,9 \%$ \\
\hline & Selffin.C & yes & $30,0 \%$ & $70,0 \%$ & $16,0 \%$ & $84,0 \%$ & $17,6 \%$ & $82,4^{\circ}$ \\
\hline & & Total & $40,2 \%$ & $59,8 \%$ & $23,7 \%$ & $76,3 \%$ & $26,0 \%$ & $74,0^{\circ}$ \\
\hline
\end{tabular}

Note: The cases in which the cash flow for the three-year period (CF) was lower than the investments during the period, and the company still declared that it used self-financing, are recorded in bold type. The cases in which firms decided not to use self-financing even though they had cash flow (CF) in excess of the investments are indicated in grey. 


\begin{tabular}{|c|c|c|c|c|c|c|c|c|}
\hline \multicolumn{9}{|c|}{ Table 6 - List and description of dependent and independent variables } \\
\hline & Dependent variables & Source & Year & Observations & Missing & Mean & Std. Dev. & Median \\
\hline SELFFIN_A & Dummy variable; $=1$ if self-financed investiments $>0$ & Capitalia & 2003 & 3385 & 0 & 0,722 & 0,448 & 1,000 \\
\hline SELFFIN_B & Dummy variable; $=1$ if self-financed investments $>50 \%$ & Capitalia & 2003 & 3385 & 0 & 0,501 & 0,500 & 1,000 \\
\hline SELFFIN_C & Dummy variable; $=1$ if investiments are fully self-financed & Capitalia & 2003 & 3385 & 0 & 0,267 & 0,442 & 0,000 \\
\hline SELFFIN_\% & Proportion of investment covered by self-finance & Capitalia & 2003 & 3385 & 0 & 0,482 & 0,410 & 0,500 \\
\hline SELFFIN_LEV & Proportion of investment covered by self-finance $\mathrm{x}$ Investments in Euro $(\mathrm{x} 1000)$ & Capitalia & 2003 & 3385 & 0 & 1739,460 & 14340,000 & 113,097 \\
\hline SELFFIN_RATE & Self-finance for investments / Total assets & Capitalia and Aida & $2001-03$ & 3385 & 0 & 0,017 & 0,059 & 0,005 \\
\hline \multicolumn{9}{|c|}{ Explanatory variables } \\
\hline \multicolumn{9}{|c|}{ Firm's structural and financial characteristics } \\
\hline AGE & $\mathrm{Ln}$ of the years in operation of the firm & Capitalia & 2003 & 3385 & 0 & 3,128 & 0,737 & 3,219 \\
\hline TOTAL ASSETS & Ln of total assets & Capitalia & 2003 & 3171 & 214 & 9,194 & 1,304 & 9,152 \\
\hline HI-ТЕСН & If the firm belongs to Hi-Tech sector & Capitalia & 2003 & 3385 & 0 & 0,048 & 0,213 & 0,000 \\
\hline GROUP & Dummy variable; $=1$ if membership of a group & Capitalia & 2003 & 3379 & 6 & 1,680 & 0,467 & 0,000 \\
\hline TURNOVER & $\%$ variation in turnover $2002-2003$ & Aida & $2002-03$ & 3172 & 213 & 8,065 & 273,094 & $-0,006$ \\
\hline LEVERAGE & Debt / Total assets & Aida & 2001-03 & 3134 & 251 & 0,715 & 0,186 & 0,750 \\
\hline ROS & Return on sales & Aida & 2001-03 & 3171 & 214 & 1,180 & 0,555 & 1,108 \\
\hline ROI & ROI - Return on investment & Aida & 2001-03 & 3130 & 255 & 5,691 & 6,342 & 5,040 \\
\hline RO_SD & Standard deviation of operating result $1996-2003$ & Aida & $1996-03$ & 3158 & 227 & 941,956 & 4729,260 & 247,946 \\
\hline ROI_SD & Standard deviation of ROI 1996-2003 & Aida & $1996-03$ & 3133 & 252 & 3,959 & 2,664 & 3,268 \\
\hline CURRENT_RATIO & Current assets / Current liabilities & Aida & 2001-03 & 3171 & 214 & 1,503 & 1,115 & 1,234 \\
\hline CASH_FLOW & & Aida & & & & & & \\
\hline CASH_FLOW_RATE & Cash Flow / Total assets & Aida & 2001-03 & 3330 & 55 & 0,067 & 0,091 & 0,058 \\
\hline NET_CASH_FLOW_RATE & Dummy variable; $=1$ if Cash Flow $>$ Investments & Capitalia and Aida & 2001-03 & 3385 & 0 & 0,742 & 0,438 & 1,000 \\
\hline NET_CASH_FLOW_RD_RATE & Dummy variable; $=1$ if Cash Flow > Expenses in $R \& D$ & Capitalia and Aida & 2001-03 & 3385 & 0 & 0,904 & 0,295 & 1,000 \\
\hline INV_RATE & Investments / Total assets & Capitalia and Aida & 2001-03 & 3385 & 0 & 0,040 & 0,083 & 0,024 \\
\hline RD_INV_RATE & Expenses in R\&D/ Total assets & Capitalia and Aida & $2001-03$ & 3385 & 0 & 0,009 & 0,058 & 0,000 \\
\hline \multicolumn{9}{|c|}{ Information asymmetries } \\
\hline TANGIBLE & Tangible assets / Total assets & Capitalia & 2003 & 3171 & 214 & 0,462 & 0,167 & 0,466 \\
\hline OPACITY & Intangible assets / Tangible assets & Aida & 2001-03 & 3050 & 335 & 0,917 & 36,681 & 0,033 \\
\hline NUMBANKS & Number of Bank relationships & Capitalia & 2003 & 3359 & 26 & 5,878 & 3,555 & 5,000 \\
\hline MAIN BANK & Proprotion of debt with main bank & Capitalia & 2003 & 3073 & 312 & 31,302 & 25,274 & 30,000 \\
\hline LOCAL BANK & Dummy variabile; $=1$ if local bank has registered office in same province as firm & Capitalia & 2003 & 3334 & 51 & 1,443 & 0,497 & 1,000 \\
\hline RATIONING & Dummy variable; $=1$ if the firm would like more credit & Capitalia & 2003 & 3340 & 45 & 1,858 & 0,349 & 0,000 \\
\hline DURATION & Age of relationship with main bank & Capitalia & 2003 & 3225 & 160 & 16,877 & 12,278 & 15,000 \\
\hline \multicolumn{9}{|c|}{ Banking market characteristics } \\
\hline BRANCHES & Number of branches by region & Bank of Italy & 2003 & 3385 & 0 & 3128,670 & 1804,970 & 3148,000 \\
\hline HHI_LOAN & Herfindal index of loans by region & Bank of Italy & 2003 & 3385 & 0 & 0,073 & 0,027 & 0,067 \\
\hline
\end{tabular}




\begin{tabular}{|c|c|c|c|c|c|}
\hline \multicolumn{6}{|c|}{ Table 7 - Financing of investment activities } \\
\hline & $\begin{array}{c}\text { Self-finance } \\
>0\end{array}$ & $\begin{array}{c}\text { Self-finance } \\
>50 \%\end{array}$ & $\begin{array}{l}\text { Self-finance } \\
=100 \%\end{array}$ & & \\
\hline & model 1 & model 2 & model 3 & model 4 & model 5 \\
\hline & logit & logit & logit & OLS & $O L S$ \\
\hline \multicolumn{6}{|c|}{ Firm's structural and financial characteristics } \\
\hline AGE & 0,13070 & 0,05620 & 0,02370 & 0,02147 & $0,003050^{* *}$ \\
\hline TOTAL ASSETS & 0,17510 & 0,12740 & 0,03460 & $0,044350^{\text {रakt }}$ & $-0,000027$ \\
\hline HI-TECH & 0,72770 & 0,41150 & 0,27190 & $0,08421^{*}$ & 0,000795 \\
\hline GROUP & 0,12310 & 0,16870 & 0,09230 & 0,00028 & 0,002790 \\
\hline TURNOVER & 0,23010 & 0,00007 & 0,00073 & 0,00008 & 0,000006 \\
\hline LEVERAGE & $-1,90380^{*}$ & $-1,89700$ & $-1,25740^{\text {*** }}$ & $-0,28910^{* * *}$ & $-0,00995^{*}$ \\
\hline ROS & 0,06200 & $0,186400^{* *}$ & $0,247300^{* * * *}$ & $0,05414^{* * *}$ & 0,002740 \\
\hline ROI & 0,01080 & 0,10500 & 0,01370 & 0,00267 & 0,000288 \\
\hline CURRENT RATIO & 0,01750 & 0,07490 & $0,13710 *$ & $0,02336{ }^{*}$ & $-0,000404$ \\
\hline CASH_FLOW_RATE & 0,97940 & $-0,63210$ & $-3,94410^{* *}$ & $-0,36379^{*}$ & 0,196980 * \\
\hline NET_CASH_FLOW_INV & 0,28110 & 0,50980 & 0,42260 * & $0,11761^{*+7}$ & $-0,023720$ \\
\hline NET_CASH_FLOW_RD & $-0,481400^{*}$ & $-0,53460^{* * *}$ & $-0,40030^{*}$ & $-0,09437^{* *}$ & $-0,001730$ \\
\hline RO_SD & 0,00004 & $0,00008^{* *}$ & $0,00004^{* *}$ & $0,00001^{*}$ & 0,000288 \\
\hline ROI_SD & $-0,00810$ & 0,00396 & $0,05260 *$ & $0,00674^{*+1}$ & 0,000297 \\
\hline INVESTMENT_RATE & 0,88790 & $-3,05170$ & $-8,03100$ & $-0,18349$ & \\
\hline \multicolumn{6}{|c|}{ Information asymmetries and relationship lending } \\
\hline NUMBANKS & $-0,04100$ & $-0,09980$ & $-0,12130$ * & 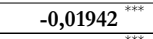 & $-0,000287$ \\
\hline MAIN BANK & $-0,00533^{*}$ & $-0,01020$ & $-0,00927^{*}$ & $-0,00181^{* * * *}$ & 0,000030 \\
\hline DURATION & 0,00654 & 0,00410 & 0,00314 & 0,00059 & $-0,000060$ \\
\hline LOCAL BANK & $-0,07200$ & $-0,12130$ & $-0,19330$ & $-0,04370^{*}$ & $-0,000911$ \\
\hline RATIONING & $-0,39870$ * & $-0,32080$ * & $-0,25410$ & $-0,08597^{* * * *}$ & $-0,005220$ ** \\
\hline OPACITY & 0,00084 & $-0,09680^{*}$ & $-0,04360$ & $-0,00008$ & 0,000001 \\
\hline TANGIBLE & $-0,13910$ & $-0,36940$ & $-0,70930^{* *}$ & $-0,01240$ & $0,013600^{* * *}$ \\
\hline \multicolumn{6}{|l|}{ Banking market characteristics } \\
\hline NUM_BRANCHES & 0,00001 & $0,00009 *$ & 0,00005 * & $0,00001^{* * *}$ & $0,000001^{* *}$ \\
\hline LOAN_HHI & 0,44890 & 0,07820 & $-6,23510^{*}$ & 0,31075 & 0,007400 \\
\hline Number of observations & 2264 & 2264 & 2264 & 2264 & 2264 \\
\hline Pseudo R2 & 0,3262 & 0,1810 & 0,4342 & 0,6280 & 0,2175 \\
\hline
\end{tabular}

\begin{tabular}{|c|c|c|c|}
\hline \multicolumn{4}{|c|}{ Table 8 - Heckman self-selection model } \\
\hline & \multicolumn{3}{|c|}{ Two-step self-selection model } \\
\hline & SELFFIN & & SELFFIN_RATE \\
\hline & $\begin{array}{l}\text { Self-financ } \\
\text { Selection Stag }\end{array}$ & & Specification Stage \\
\hline \multirow{15}{*}{$\begin{array}{l}\text { CASH_FLOW_RATE } \\
\text { NET_CASH_FLOW_INV } \\
\text { RATIONING } \\
\text { LEVERAGE }\end{array}$} & $1,60896^{* * *}$ & CURRENT RATIO & $0,00133^{* *}$ \\
\hline & $0,11692^{* *}$ & TOTAL ASSETS & $0,00281^{* * *}$ \\
\hline & $-0,45232^{* * *}$ & ROS & $0,00302^{* *}$ \\
\hline & $-0,73529^{* * *}$ & ROI & $0,00031^{* *}$ \\
\hline & & NET_CASH_FLOW_RD & $-0,01648^{* * *}$ \\
\hline & & RD_INV_RATE & $-0,42757^{* * *}$ \\
\hline & & NUM_BANKS & $-0,00081^{* * *}$ \\
\hline & & LOAN_HHI & $-0,04486^{* *}$ \\
\hline & & LEVERAGE & 0,00300 \\
\hline & & GROUP & $-0,00129$ \\
\hline & & TANGIBLE & $-0,00066$ \\
\hline & & OPACITY & 0,00000 \\
\hline & & RATIONING & 0,00101 \\
\hline & & HI-TECH & $0,00576^{* *}$ \\
\hline & & DURATION & $-0,00004$ \\
\hline Lambda & $-0,02055^{* *}$ & Rho & $-0,66602$ \\
\hline $\mathrm{N}$ & 2740 & Sigma & 0,03085 \\
\hline Wald Chi2 & $4107,89^{* * *}$ & & \\
\hline \multicolumn{4}{|c|}{$\begin{array}{l}\text { Note: } * * *=\text { significant at } 0.001 ; * *=\text { significant at } 0.01 ; *=\text { significant at } \\
0.05 \text {. }\end{array}$} \\
\hline
\end{tabular}


